\title{
Lactobacillus cypricasei sp. nov., isolated from Halloumi cheese
}

\author{
Paul A. Lawson, ${ }^{1}$ Photis Papademas, ${ }^{1}$ Carmen Wacher, ${ }^{1,2}$ Enevold Falsen, ${ }^{3}$ \\ Richard Robinson ${ }^{1}$ and Matthew D. Collins ${ }^{1}$
}

Author for correspondence: Paul A. Lawson. Tel: +44 1189357000 . Fax: +44 1189357222.

e-mail:p.a.lawson@reading.ac.uk

\footnotetext{
1 Department of Food Science and Technology, University of Reading, Reading RG6 6AP, UK

2 Departamento de Alimentos and Biotecnología, Facultad de Química, Universidad Nacional Autónoma de México, Mexico

3 Culture Collection, Department of Clinical Bacteriology, University of Göteborg, Göteborg S-413 46, Sweden
}

\begin{abstract}
Four strains of a hitherto unknown bacterium isolated from Halloumi cheese were compared by using phenotypic and phylogenetic studies. Comparative $16 S$ rRNA gene sequencing demonstrated that the strains were identical to each other and represent a new subline within the genus Lactobacillus. The unknown bacterium was readily distinguished from other described Grampositive catalase-negative taxa by means of biochemical tests and electrophoretic analysis of whole-cell proteins. On the basis of phylogenetic and phenotypic evidence, it is proposed that the unknown bacterium be classified as Lactobacillus cypricasei sp. nov. The type strain of $L$. cypricase $i$ is CCUG $42961^{\top}\left(=\right.$ CIP $\left.106393^{\top}\right)$.
\end{abstract}

Keywords: Lactobacillus cypricasei, Halloumi cheese, 16S rRNA, taxonomy, phylogeny

\section{INTRODUCTION}

The lactic acid bacteria possess a large number of metabolic properties that are responsible for their successful use as starter cultures in the commercial production of fermented dairy, meat and vegetable products and beverages (Hammes et al., 1992; Stiles \& Holzapfel, 1997; Wibowo et al., 1985). The genus Lactobacillus represents the largest group of rodshaped organisms within the lactic acid bacteria: currently, over 60 species are recognized. Some members of this group of organisms are important in the generation of particular flavours and in other ripening processes associated with specific cheeses (Elsoda, 1993; Elortondo et al., 1998; Fitzsimons et al., 1999; Hong et al., 1998). Halloumi cheese originated in Cyprus, but its appeal has spread worldwide. It is semi-hard, elastic, has no obvious skin/rind, has a close texture with no holes and is easily sliced. The colour varies from white (when a mixture of ovine/caprine milk is used) to yellowish (when bovine milk is the main ingredient). A feature of the production method of this particular cheese is that no starter cultures are used; rather, the flavour and texture depend solely on the indigenous microflora of the milk (Papademas \& Robinson, 1998). During the

\footnotetext{
Abbreviation: MRD, maximum recovery diluent.
}

The GenBank accession number for the 16S rRNA gene sequence of strain CCUG $42961^{\top}$ is AJ251560. course of a study to determine the microflora of Halloumi cheese, organisms corresponding to Lactobacillus brevis, Lactobacillus pentosus, Lactobacillus plantarum and Enterococcus faecium were recovered. In addition, a hitherto unknown Lactobacillus-like bacterium was isolated. In this article, we report the characteristics of this unknown lactic acid bacterium and the results of a polyphasic taxonomic study. On the basis of the results of this study, a new Lactobacillus species, Lactobacillus cypricasei sp. nov., is described.

\section{METHODS}

Bacterial strains and cultivation. Strains LMK1, LMK2 and LMK 3 were isolated from Halloumi cheese in which ovine milk from a dairy located in the province of Paphos, Cyprus was used as the major ingredient. Strain LMD2 was isolated from Halloumi cheese made from ovine milk from a dairy located in the province of Nicosia, Cyprus. The cheesemaking processes were as described previously (Papademas $\&$ Robinson, 1998). Two blocks of cheese of each type were unwrapped and cut in half. One portion was then shredded with a grater and $10 \mathrm{~g}$ weighed into a stomacher bag. The cheese was then blended with $90 \mathrm{ml}$ maximum recovery diluent (MRD; catalogue no. CM 733; Oxoid, Unipath) and serial dilutions made to $10^{6}$ using MRD. Duplicate aliquots from each dilution were put onto MRS agar (De Man et al., 1960) and incubated aerobically at $37^{\circ} \mathrm{C}$ for $72 \mathrm{~h}$. Total colony counts were taken and the plates examined with a hand-lens in order to establish the dominant colony types. Five colonies each of the predominant types were taken and subcultured on MRS agar. Strains LMK1, LMK2, LMK3 
and LMD2 have been deposited in the Culture Collection of the University of Göteborg (CCUG) under accession numbers 42959, 42960, 42961 ${ }^{\mathrm{T}}$ and 42962 , respectively.

Biochemical characterization. The strains were biochemically characterized by using the API rapid ID32 Strep, API ZYM and API CH50 systems according to the instructions of the manufacturer (API bioMérieux). The type strains and other reference strains used in the investigation were all maintained by the CCUG, Sweden. All tests were performed in duplicate.

SDS-PAGE of whole-cell proteins. To assess the overall phenotypic resemblance of the new isolate and reference species, a comparative analysis of whole-cell protein profiles by SDS-PAGE was performed. PAGE analysis of whole-cell proteins was carried out as described by Pot et al. (1994) and Vandamme et al. (1998). For densitometric analysis, normalization and interpretation of protein patterns, the GCW version 3.0 software package (Applied Maths) was used. For each pair of traces, the similarity was expressed by the Pearson product moment correlation coefficient, converted (for convenience) to a percentage similarity.

Determination of 16S rRNA gene sequences and phylogenetic analysis. Phylogenetic analysis was performed by using comparative $16 \mathrm{~S}$ rRNA gene sequence analyses. A large fragment of the $16 \mathrm{~S}$ rRNA gene (corresponding to positions 30 to 1521 of the Escherichia coli $16 \mathrm{~S}$ rRNA gene) was amplified by a PCR using conserved primers close to the $3^{\prime}$ - and 5'-ends of the gene. The PCR products were directly sequenced using a Taq DyeDeoxy terminator cyclesequencing kit (Applied Biosystems) and an automatic DNA sequencer (model 373A; Applied Biosystems). The closest known relatives of the new isolate were determined by performing database searches. These sequences and those of other known related strains were retrieved from the EMBL or Ribosomal Database Project databases and aligned with the newly determined sequences by using the program PILEUP (Devereux et al., 1984). The resulting multiple sequence alignment was corrected manually and approximately 100 bases at the 5 '-end of the rRNA were omitted from further analyses because of alignment ambiguities. Pairwise evolutionary distances were computed from a continuous stretch of 1320 bases by using the correction of Jukes \& Cantor (1969). A phylogenetic tree was constructed according to the neighbour-joining method with the program NEIGHBOR (Felsenstein, 1989). The stability of the groupings was estimated by bootstrap analysis (500 replications) using the programs SEQBOOT, DNADIST, NEIGHBOR and CONSENSE (Felsenstein, 1989).

\section{RESULTS AND DISCUSSION}

All four strains consisted of Gram-positive, non-sporeforming, rod-shaped organisms, which occurred as single cells, pairs or short chains. The mean dimensions of the rods were $0.6-0.8 \mu \mathrm{m}$ (width) and 3-5 $\mu \mathrm{m}$ (length) and they had rounded ends (Fig. 1). The isolates were facultatively anaerobic and catalase- and oxidase-negative. No growth was observed at 15 or $45^{\circ} \mathrm{C}$ in MRS broth after $48 \mathrm{~h}$ incubation. With commercial API systems, acid was produced from arbutin, cellobiose, galactose, glucose, D-fructose, D-mannose and salicin but not from D-arabinose, adonitol, Darabitol, cyclodextrin, dulcitol, erythritol, D-fucose, L-fucose, glycogen, inositol, mannitol, melibiose,

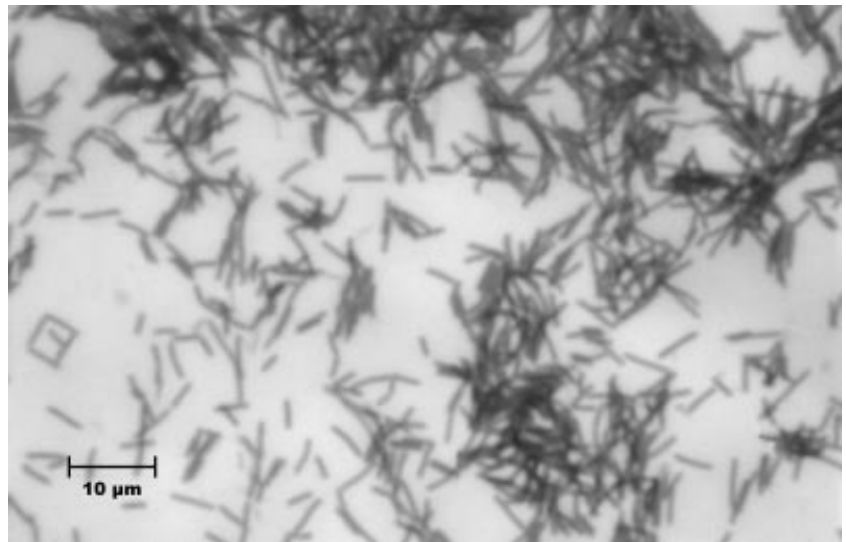

Fig. 1. Photomicrograph of Lactobacillus cypricasei sp. nov., after $24 \mathrm{~h}$ growth in maximum recovery diluent broth, showing the typical rod-shaped morphology.

melezitose, methyl $\beta$-D-glucopyranoside, pullulan, sorbitol, tagatose, D-raffinose or D-xylose. Acid production from L-arabinose, lactose, sucrose and trehalose was found to be variable. Results for acid production from ribose, maltose and $N$-acetyl- $\beta$-glucosamine differed according to the different API systems employed. With the API CH50 kit, acid was produced with these substrates, but, with the API rapid ID32 Strep system, these substrates were not fermented. Gas was not produced from glucose. The isolates gave positive reactions for arginine dihydrolase, $\beta$-galactosidase, $\beta$-galacturonidase, $\alpha$-glucosidase, $\beta$-glucosidase, leucine arylamidase, pyroglutamic acid arylamidase (weak reaction) and valine arylamidase. Negative reactions were observed for alanine phenylalanine proline arylamidase, alkaline phosphatase, chymotrypsin, esterase C-4, ester lipase $\mathrm{C} 8, \alpha$-fucosidase, $\beta$-glucuronidase, glycine-tryptophan arylamidase, lipase $\mathrm{C} 14, \beta$-mannosidase, trypsin and urease. Variable reactions were obtained for acid phosphatase, cystine arylamidase, $\alpha$-galactosidase, $\alpha$ mannosidase and phosphoamidase. All of the isolates hydrolysed aesculin but not hippurate and gave positive VP test results.

In terms of their cultural and biochemical characteristics, the isolates from Halloumi cheese resembled the genus Lactobacillus but did not correspond to any recognized species. To investigate the overall phenotypic resemblance of the unknown cheese isolates to each other and to species of the genus Lactobacillus, whole-cell protein profiles were determined. A numerical analysis of the PAGE protein patterns of the unknown Lactobacillus-like strains together with some reference species of Lactobacillus are shown in Fig. 2. The four cheese isolates clustered together and formed a distinct group with a correlation level of $85 \%$. L . brevis CCUG $30670^{\mathrm{T}}$ was the species nearest to the unknown isolates, joining the latter group at a correlation of approximately $65 \%$ (Fig. 2). Other Lactobacillus species were more distantly related. The PAGE 


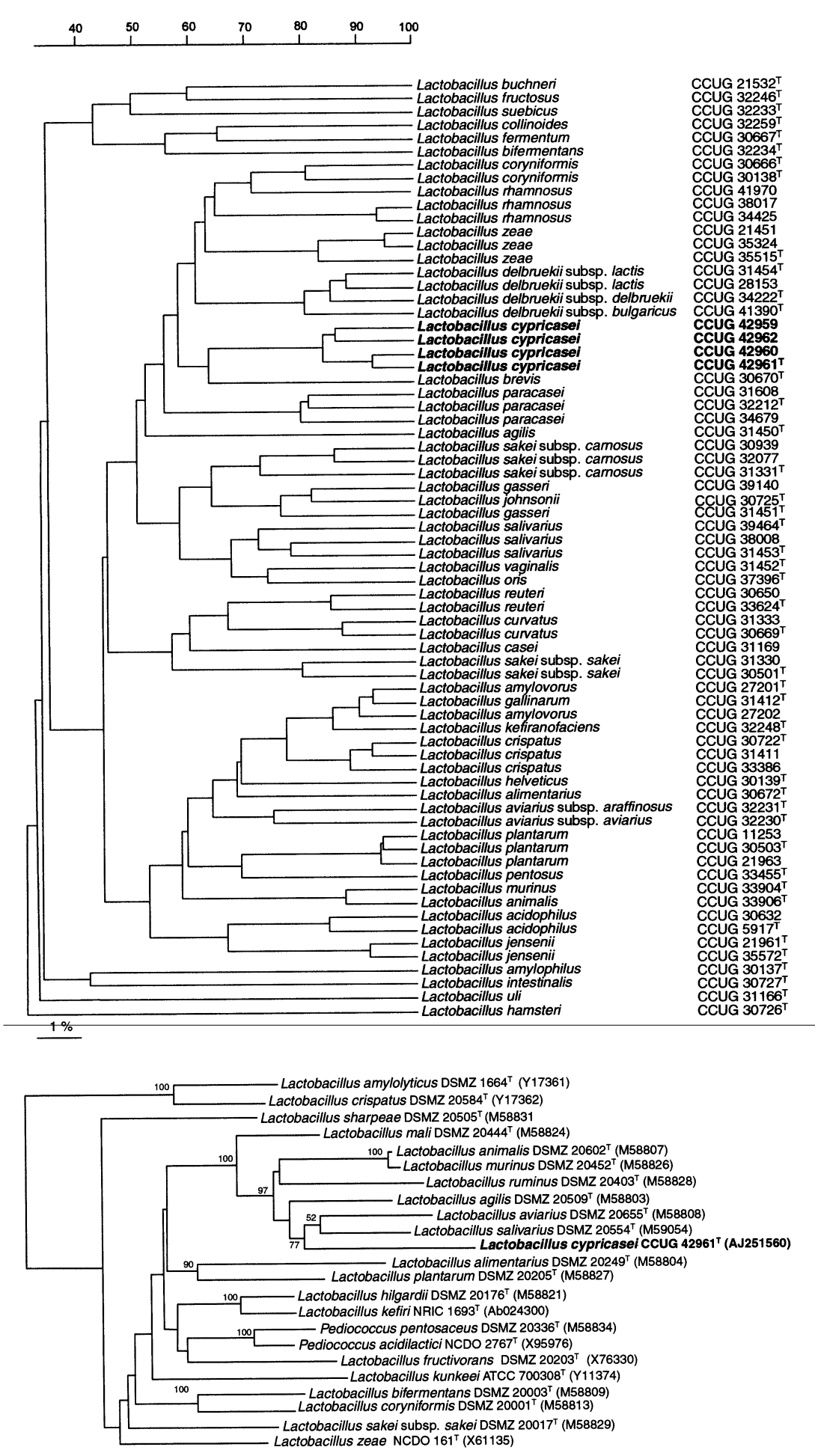

Fig. 2. Similarity dendrogram based on whole-cell protein patterns of $L$. cypricasei sp. nov. and related species. Patterns between 20 and $120 \mathrm{kDa}$ were used in the construction of the dendrogram. Levels of correlation are expressed as percentages of similarity for convenience.
Fig. 3. Unrooted tree showing the phylogenetic relationships of $L$. cypricasei $\mathrm{sp}$. nov. and some related Gram-positive bacteria. The tree constructed using the neighbour-joining method was based on a comparison of approximately 1327 nucleotides. Bootstrap values, expressed as percentages of 500 replications, are given at the branching points. Bar, $1 \%$ sequence divergence. results demonstrated that the four lactic acid strains represent a phenotypically homogeneous group of organisms and are separate from the other Lactobacillus species investigated.

To ascertain the phylogenetic relationships of the unknown isolates, their 16S rRNA genes were sequenced and subjected to a comparative analysis. The almost complete gene sequences ( $>1450$ nucleotides) of the four strains were determined and pairwise analysis showed them to be identical $(100 \%$ sequence similarity), thereby demonstrating the high level of genealogical relatedness of the isolates. Sequence database searches showed that the unknown bacterium 
Table 1. Characteristics that differentiate Lactobacillus cypricasei sp. nov. from some of its nearest phylogenetic relatives

Biochemical tests were performed using API rapid ID32 Strep, API ZYM and API CH50 systems (API bioMérieux). v, Variable.

\begin{tabular}{|c|c|c|c|c|c|c|c|}
\hline Test & L. agilis & L. animalis & L. aviarius & L. cypricasei & L. murinus & L. ruminis & L. salivarius \\
\hline \multicolumn{8}{|l|}{ Production of acid from: } \\
\hline Galactose & + & + & - & + & + & + & + \\
\hline Mannitol & + & - & - & - & - & - & + \\
\hline D-Ribose & + & + & - & $\mathrm{v}$ & + & - & - \\
\hline D-Raffinose & + & + & - & - & $\mathrm{v}$ & + & + \\
\hline Sorbitol & - & - & - & - & - & - & + \\
\hline \multicolumn{8}{|l|}{ Production of: } \\
\hline $\begin{array}{l}\text { Alanine phenylalanine } \\
\text { proline arylamidase }\end{array}$ & + & + & + & - & + & + & + \\
\hline$N$-Acetyl $\beta$-glucosaminidase & + & + & - & $\mathrm{v}$ & + & + & + \\
\hline Arginine dihydrolase & - & - & - & + & - & - & - \\
\hline$\alpha$-Galactosidase & + & + & $\mathrm{v}$ & $\mathrm{v}$ & + & + & + \\
\hline
\end{tabular}

was most closely related to species of rRNA group II (Lactobacillus casei/Pediococcus group) of the genus Lactobacillus (see Collins et al., 1991). The results of neighbour-joining analysis are shown in Fig. 3 and confirmed the association between the unknown bacterium from Halloumi cheese (as exemplified by strain CCUG $42961^{\mathrm{T}}$ ) and rRNA group II of the genus Lactobacillus. The unknown bacterium formed a distinct subline within a cluster of species which includes Lactobacillus agilis, Lactobacillus aviarius, Lactobacillus animalis, Lactobacillus murinus, Lactobacillus ruminus and Lactobacillus salivarius (92$93.3 \%$ sequence similarity) and was supported by a bootstrap value of $97 \%$. The highest levels of sequence relatedness were found with $L$. aviarius (originally isolated from the intestines and faeces of chickens; Fujisawa et al., 1984) and L. salivarius (found in the intestinal tracts of humans and animals; Rogosa et al., 1953), each of which showed a sequence divergence value of $7 \%$ with respect to the unknown bacterium. It is clear from the investigation that the Lactobacilluslike strains recovered from Halloumi cheese represent a homogeneous group of organisms that are phenotypically distinct from currently recognized members of the genus. Phylogenetically, the unknown bacteria form a distinct subline within the genus; the 7\% (or more) sequence divergence values observed with other lactobacilli unequivocally demonstrate that the isolates from cheese warrant classification as a new species of the genus Lactobacillus, for which the name $L$. cypricasei sp. nov. is proposed. The characteristics that are useful in distinguishing $L$. cypricase $i$ from its closest phylogenetic relatives are shown in Table 1.

\section{Description of Lactobacillus cypricasei sp. nov.}

Lactobacillus cypricasei (cy.pri.ca'se.i. N.L. masc. gen. n. cypricasei of cheese from Cyprus, referring to the original isolation source).
The cells are Gram-positive, non-spore-forming, rodshaped and occur as single cells, pairs or short chains. The rods are $0 \cdot 6-0.8 \mu \mathrm{m}$ wide $\times 3-5 \mu \mathrm{m}$ long, with rounded ends. When grown on MRS agar, colonies are small, entire and cream-coloured. Facultatively anaerobic. Catalase- and oxidase-negative. No growth is observed at 15 or $45^{\circ} \mathrm{C}$ in MRS broth after $48 \mathrm{~h}$ incubation. The optimum $\mathrm{pH}$ range is $5 \cdot 5-7 \cdot 5$. Homofermentative. No gas is produced from glucose metabolism. Acid is produced from arbutin, cellobiose, galactose, glucose, D-fructose, D-mannose and salicin but not from D-arabinose, D-arabitol, adonitol, cyclodextrin, dulcitol, erythritol, D-fucose, L-fucose, glycogen, inositol, mannitol, melibiose, melezitose, methyl $\beta$-D-glucopyranoside, pullulan, sorbitol, tagatose, D-raffinose, xylitol or D-xylose. Acidification of Larabinose, lactose, maltose, sucrose and trehalose is variable. Positive reactions are obtained for arginine dihydrolase, $\beta$-galactosidase, $\beta$-galacturonidase, $\alpha$ glucosidase, $\beta$-glucosidase, leucine arylamidase, pyroglutamic acid arylamidase (weak reaction) and valine arylamidase. Negative reactions are obtained for alanine phenylalanine proline arylamidase, alkaline phosphatase, chymotrypsin, esterase C-4, ester lipase C8, $\alpha$-fucosidase, $\beta$-glucuronidase, glycine-tryptophan arylamidase, lipase $\mathrm{C} 14, \beta$-mannosidase, trypsin and urease. Variable reactions are obtained for acid phosphatase, $N$-acetyl- $\beta$-glucosaminidase, cystine arylamidase, $\alpha$-galactosidase, $\alpha$-mannosidase and phosphoamidase. Aesculin is hydrolysed but hippurate is not hydrolysed. Acetoin is produced. Isolated from Halloumi cheese, a cheese prevalent in Cyprus. The type strain is CCUG $42961^{\mathrm{T}}\left(=\mathrm{CIP} 106393^{\mathrm{T}}\right)$.

\section{ACKNOWLEDGEMENTS}

We are grateful to Hans Trüper for help with the derivation of the species name. C. Wacher is currently on a one-year sabbatical placement at the University of Reading, funded, 
in part, by DGAPA UNAM and CONACYT, Mexico. Photis Papademas acknowledges, with gratitude, the financial support of the Cyprus Milk Industry Organization (CMIO).

\section{REFERENCES}

Collins, M. D., Rodrigues, U. M., Aguirre, M., Farrow, J. A. E., Marinez-Murcia, A., Philips, B. A., Williams, A. M. \& Wallbanks, S. (1991). Phylogenetic analysis of the genus Lactobacillus and related lactic acid bacteria as determined by reverse transcriptase sequencing of 16S rRNA. FEMS Microbiol Lett 77, 5-12.

De Man, J. C., Rogosa, M. \& Sharpe, M. E. (1960). A medium for the cultivation of lactobacilli. J Appl Bacteriol 23, 130-135.

Devereux, J., Haeberli, P. \& Smithies, O. (1984). A comprehensive set of sequence analysis programs for the VAX. Nucleic Acids Res 12, 387-395.

Elortondo, F. J. P., Echobarria, P. A., Albisu, M. \& Barcina, Y. (1998). Indigenous lactic acid bacteria in idiazabal ewes' milk cheese. Int Dairy J 8, 725-732.

Elsoda, M. A. (1993). The role of lactic-acid bacteria in accelerated cheese ripening. FEMS Microbiol Lett 12, 239-252.

Felsenstein, J. (1989). PHYLIP - phylogeny inference package (version 3.2). Cladistics 5, 164-166.

Fitzsimons, N. A., Cogan, T. M., Condon, S. \& Beresford, T. (1999). Phenotypic and genotypic characterization of non-starter lactic acid bacteria in mature cheddar cheese. Appl Environ Microbiol 65, 3418-3426.

Fujisawa, T., Shirasaka, S., Watabe, J. \& Mitsuoka, T. (1984). Lactobacillus aviarius sp. nov.: a new species isolated from the intestine of chickens. Syst Appl Microbiol 5, 414-420.
Hammes, W. P., Weiss, N. \& Holzapfel, W. (1992). The genera Lactobacillus and Carnobacterium. In The Prokaryotes, 2nd edn, pp. 1535-1594. Edited by A. Barlows, H. G. Trüper, M. Dworkin, W. Harder \& K.-H. Schleifer. New York: Springer.

Hong, Y. H., Yun, J. J., Barbano, D. M. \& Kindstedt, P. S. (1998). Impact of three commercial lactobacillus culture strains on mozzarella cheese yield. Aust J Dairy Technol 53, 170-174.

Jukes, T. H. \& Cantor, C. R. (1969). Evolution of protein molecules. In Mammalian Protein Metabolism, pp. 21-132. Edited by N. H. Munro. New York: Academic Press.

Papademas, P. \& Robinson, R. K. (1998). Halloumi cheese: the product and its characteristics. Int J Dairy Technol 51, 98-103.

Pot, B., Vandamme, P. \& Kersters, K. (1994). Analysis of electrophoretic whole-organism protein fingerprints. In Modern Microbial Methods. Chemical Methods in Prokaryotic Systematics, pp. 493-521. Edited by M. Goodfellow \& A. G. O’Donnell. Chichester: Wiley.

Rogosa, M., Wiseman, R. F., Mitchell, J. A., Disraely, M. N. \& Beaman, A. J. (1953). Species differentiation of oral lactobacilli from man including descriptions of Lactobacillus salivarius nov. spec. and Lactobacillus cellobiosus nov. spec. J Bacteriol 65 , 681-699.

Stiles, M. E. \& Holzapfel, W. H. (1997). Lactic acid bacteria of foods and their current taxonomy. Int J Food Microbiol 36, $1-29$.

Vandamme, P., Torck, U., Falsen, E., Pot, B., Goossens, H. \& Kersters, K. (1998). Whole-cell protein electrophoretic analysis of viridans Streptococcus mitis biovars. Int J Syst Bacteriol $\mathbf{4 8 ,}$ 117-125.

Wibowo, D., Eschenbruch, R., Davies, C. R., Fleet, G. H. \& Lee, T. H. (1985). Occurrence and growth of lactic acid bacteria in wine: a review. Am J Enol Viticult 36, 302-313. 